Bangladesh J. Zool. 41(1): 13-19, 2013

\title{
LIMNOLOGY OF MERBOK ESTUARY, KEDAH, MALAYSIA
}

\author{
Kaniz Fatema*, Wan Maznah Wan Omar ${ }^{1}$ and Mansor Mat Isa ${ }^{1}$ \\ School of Biological Sciences, Universiti Sains Malaysia, 11800 Penang, Malaysia
}

\begin{abstract}
Water quality in three different stations of Merbok estuary was investigated limnologically from October, 2010 to September, 2011. Water temperature, transparency and total suspended solids (TSS) varied from 27.45 $30.45^{\circ} \mathrm{C}, 7.5-120 \mathrm{~cm}$ and $10-140 \mathrm{mg} / \mathrm{l}$, respectively. Dissolved Oxygen (DO) concentration ranged from $1.22-10.8 \mathrm{mg} / 1$, while salinity ranged from 3.5-35.00 ppt. $\mathrm{pH}$ and conductivity ranged from $6.35-8.25$ and $40-380 \mu \mathrm{S} / \mathrm{cm}$, respectively. Kruskal Wallis $\mathrm{H}$ test shows that water quality parameters were significantly different among the sampling months and stations $(p<0.05)$. This study revealed that DO, salinity, conductivity and transparency were higher in wet season and TSS was higher in dry season. On the other hand, temperature and $\mathrm{pH}$ did not follow any seasonal trends.
\end{abstract}

Key words: Water quality, Merbok estuary, Malaysia

\section{INTRODUCTION}

Water is the most essential environmental element for aquatic life. No form of life can sustain without water. Water bodies, such as, lakes, rivers, ponds and estuaries are the source for water supply in domestic, industrial, agriculture and aquaculture. The Merbok River which is a mangrove estuary situated in the north-west Peninsular Malaysia. The Merbok mangroves have suffered successive periods of conversion: about 1000 ha $(20 \%)$ for irrigated rice production in the 1960s, a similar area was converted to pond aquaculture in the 1980s, and the current pressure comes from urban development at the upstream of the river (Fatema et al. 2012). Therefore, the present study was conducted to assess the trend of water quality changes in the estuary within 12 months in relationship to the seasonal variation and other activities occurring around the estuarine area. The findings of the study will play a vital role for sustainable estuarine management.

\section{MATERIAL AND METHODS}

Study area and sampling station: The River Merbok $\left(5^{\circ} 30^{\circ} \mathrm{N}, 100^{\circ} 25^{\circ} \mathrm{E}\right)$ is the opening of one of the major rivers in southern Kedah. It flows into the Straits of Malacca. The length of river is about $35 \mathrm{~km}$. The river depth varies from 3- 15 $\mathrm{m}$ (Kjerfve 1979, Ong et al. 1991). The tidal range in the nearest coastal area is

*Corresponding author: Department of Fisheries, University of Dhaka, Dhaka1000, Bangladesh. E-mail: f.kaniz@yahoo.com. ${ }^{1}$ Center for Marine and Coastal Studies (CEMACS), Universiti Sains Malaysia, 11800 Penang, Malaysia 
from $0-2.9 \mathrm{~m}$. The catchment area of Merbok River is about $550 \mathrm{~km}^{2}$. Three sampling stations were designated in this study. Station 1 (Lalang River, $\mathrm{N} \mathrm{05}{ }^{\circ}$ $\left.41^{\prime} 56.63^{\prime \prime} \mathrm{E} 100^{\circ} 30^{\prime} 16.94^{\prime \prime}\right)$ is located in the upstream whereas Station 2 (Jagung River, N $05^{\circ} 39^{\prime} 27.33^{\prime \prime} \mathrm{E} 100^{\circ} 26^{\prime} 58.00^{\prime \prime}$ ) is in the middle stream. Station 3(Gelam River, N $\left.05^{\circ} 38^{\prime} 37.68^{\circ} \mathrm{E} 100^{\circ} 25^{\prime} 4.01^{\prime \prime}\right)$ is located in the downstream where aquaculture activities were carried out. The location of the Study Stations has been shown in Fig. 1.

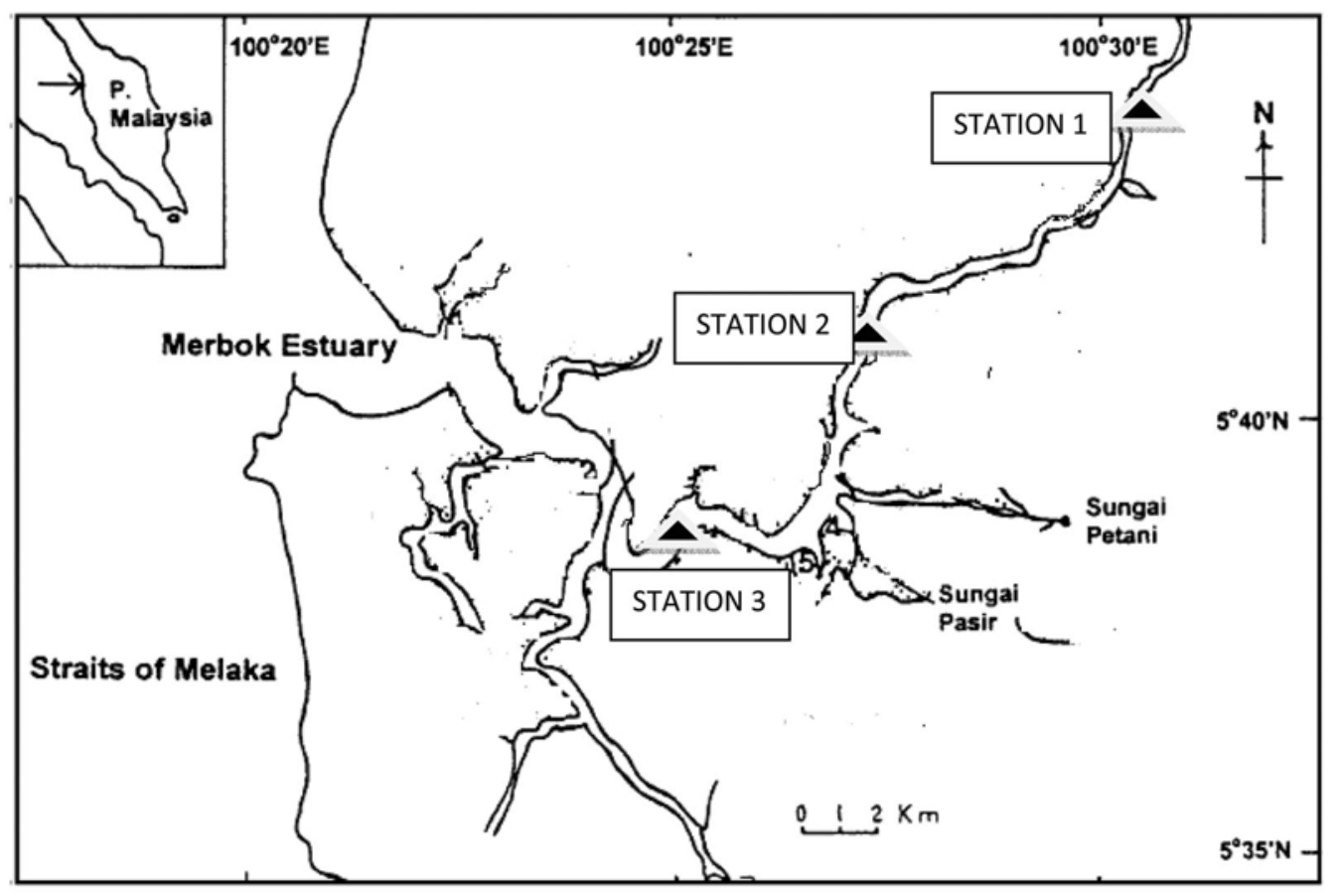

Fig.1. Location of sampling stations of Merbok estuary.

Sampling and analytical methods: Water samples were collected from October 2010 to September 2011 at monthly basis. Surface water was collected from each station (three replicates) in acid washed polythene bottles (1500 ml Cap.) for laboratory analysis. All the samples were kept in the dark and cool (temperature $4^{\circ} \mathrm{C}$ ) in the cool box and transported to a laboratory. Water temperature, dissolved oxygen (DO), salinity and electrical conductivity were measured in situ using HYDROLAB SRV3-DL (Surveyor3 Data Logger). pH was measured by a $\mathrm{pH}$ meter. Water transparency was observed using Secchi disc, $20 \mathrm{~cm}$ in diameters. TSS was measured in accordance with the standard methods (APHA 1991). Non parametric tests were used to observe significant differences between the sampling month and stations ( $\mathrm{p}<0.05$ ) (Ho 2006, and Coakes et al. 2006). 


\section{RESULTS AND DISCUSSION}

The descriptive statistics including mean, range and SD for in situ parameters of 3 sampling stations for 12 months period are presented in Table 1.

Table1. Mean \pm SD and ranges of some physicochemical parameters of Merbok estuary

\begin{tabular}{|c|c|c|c|c|c|c|c|c|}
\hline $\begin{array}{l}\text { Sta- } \\
\text { tions }\end{array}$ & & $\begin{array}{l}\text { Tempera- } \\
\text { ture }\left({ }^{\circ} \mathrm{C}\right)\end{array}$ & $\begin{array}{l}\text { Conduc- } \\
\text { tivity }(\mu \mathrm{S} / \\
\mathrm{cm})\end{array}$ & $\begin{array}{l}\text { Salinity } \\
\text { (ppt) }\end{array}$ & $\begin{array}{c}\mathrm{DO} \\
(\mathrm{mg} / \mathrm{l})\end{array}$ & $\mathrm{pH}$ & $\begin{array}{l}\text { Trans- } \\
\text { parency } \\
(\mathrm{cm})\end{array}$ & $\begin{array}{l}\text { TSS } \\
(\mathrm{mg} / 1)\end{array}$ \\
\hline \multirow[t]{2}{*}{1} & Mean \pm SD & $\begin{array}{l}29.63 \\
\pm 1.03\end{array}$ & $\begin{array}{c}177.6 \\
\pm 61.73\end{array}$ & $\begin{array}{r}13.02 \\
\pm 4.39\end{array}$ & $\begin{array}{c}4.48 \pm \\
2.10\end{array}$ & $\begin{array}{c}6.85 \\
\pm 0.39\end{array}$ & $\begin{array}{l}56.8 \pm \\
40.17\end{array}$ & $\begin{array}{c}27.50 \pm \\
11.38\end{array}$ \\
\hline & Range & $\begin{array}{c}27.45- \\
30.6\end{array}$ & $\begin{array}{l}40- \\
250\end{array}$ & $\begin{array}{l}3.5- \\
17.5\end{array}$ & $\begin{array}{c}1.22 \\
-10.8\end{array}$ & $\begin{array}{r}6.35 \\
-7.65\end{array}$ & $9-120$ & $10-46.6$ \\
\hline \multirow[t]{2}{*}{2} & Mean \pm SD & $\begin{array}{r}29.86 \\
\pm 1.03\end{array}$ & $\begin{array}{r}270.25 \\
\pm 82.44\end{array}$ & $\begin{array}{r}20.16 \\
\pm 5.60\end{array}$ & $\begin{array}{c}3.41 \pm \\
1.22\end{array}$ & $\begin{array}{c}6.97 \\
\pm 0.26\end{array}$ & $\begin{array}{c}40.7 \pm \\
19.68\end{array}$ & $\begin{array}{c}32.50 \pm \\
13.04\end{array}$ \\
\hline & Range & $\begin{array}{l}27.5- \\
30.8\end{array}$ & $\begin{array}{l}105- \\
365\end{array}$ & $\begin{array}{l}11.75 \\
-27.0\end{array}$ & $1.8-5.9$ & $6.7-7.65$ & $11-77$ & $10-53.33$ \\
\hline \multirow[t]{2}{*}{3} & Mean \pm SD & $\begin{array}{r}29.59 \\
\pm 1.00\end{array}$ & $\begin{array}{r}289.85 \\
\pm 61.53\end{array}$ & $\begin{array}{r}22.87 \\
\pm 7.42\end{array}$ & $\begin{array}{c}3.64 \pm \\
1.59\end{array}$ & $\begin{array}{c}7.2 \pm \\
0.367\end{array}$ & $\begin{array}{c}56.71 \pm \\
33.92\end{array}$ & $\begin{array}{c}38.61 \pm \\
18.06\end{array}$ \\
\hline & Range & $\begin{array}{l}27.45 \\
-30.5\end{array}$ & $\begin{array}{c}175- \\
367.5\end{array}$ & $\begin{array}{l}12.5 \\
-40\end{array}$ & $\begin{array}{c}2.2 \\
-6.7\end{array}$ & $6.9-8.1$ & $10-110.1$ & $\begin{array}{l}16.66- \\
86.66\end{array}$ \\
\hline
\end{tabular}

Temperature: The mean water temperature for 12 months sampling was $29.73 \pm 0.96^{\circ} \mathrm{C}$, which ranged from $27.45-30.45^{\circ} \mathrm{C}$. The estuarine water was competent to retain heat, therefore during low precipitation months, the water temperature exceeded $30^{\circ} \mathrm{C}$. The water temperature showed downward trend from October 2010 to February 2011 due to high precipitation rate. Water temperature varied from $29.29-29.78^{\circ} \mathrm{C}$. The minimum water temperature was recorded during the dry season at Station 1 and maximum was recorded during the wet season at Station 2. Physicochemical parameters were significantly affected by water temperature (Bellos and Sawidis 2005). Lewis (2000) and Adams et al. (2001) mentioned that high temperatures in water can rapidly regenerating the nutrient through microbial action. The results of our present study has similarly with the above findings.

Conductivity: The mean conductivity in Merbok estuary was 260.93 \pm 76.76 $\mu \mathrm{S} / \mathrm{cm}$, which ranged from $40-380 \mu \mathrm{S} / \mathrm{cm}$. The highest and lowest conductivity was recorded in March and December with the values of 339.08 and 148.33 $\mu \mathrm{S} / \mathrm{cm}$, respectively. Conductivity varied from $191.25-303.42 \mu \mathrm{S} / \mathrm{cm}$, the minimum was observed during the dry season at Station 1 and maximum was recorded during the wet season at Station 3. The sewage treatment plants, agricultural runoff and rainwater drainages caused the high variability in conductivity values (Adams et al. 2001). Atobatele and Ugwumba (2008) observed that low precipitation could increase conductivities because higher atmospheric temperatures resulting in higher total ionic concentration and 
saline intrusion from underground sources. It might also be due to a high rate of decomposition and mineralization by microbes and nutrient regeneration from bottom sediment. High conductivity values can be indicated as an increase in the amount of polluting particles. Our findings comply with the previous study.

$p H$ : The mean $\mathrm{pH}$ value in Merbok estuary was $7.07 \pm 0.38$, which ranged from $6.35-8.25$. $\mathrm{pH}$ was found to be the most stable parameter which did not show drastic changes among sampling stations (Table 1 ). Seasonal fluctuations in $\mathrm{pH}$ in water varied from $6.8-7.25$, the minimum was observed at Station 1 and maximum was recorded at Station 2 during the dry season. During wet season $\mathrm{pH}$ showed upward trends from upstream to downstream. $\mathrm{pH}$ value in this study was recorded lower in wet season than dry season. These were probably caused by the leachates and rain-runoff water from watershed areas. Rain water contains nitric, as well as sulfuric acid, hence contributing to the lower $\mathrm{pH}$ in the receiving waters (Horne and Goldman 1994).

Dissolved oxygen (DO): The DO concentration in Merbok estuary ranged from $1.22-10.8 \mathrm{mg} / 1$ with a mean value of $3.86 \pm 1.96$. DO in water varied from $2.52-5.15 \mathrm{mg} / 1$ with the minimum at Station 3 during dry season and the maximum is in $5.14 \mathrm{mg} / 1$ (Station 1) during wet season. $\mathrm{pH}$ fluctuations and DO concentrations regulate most of the biochemical and chemical reactions that can affect water composition (Bellos and Sawidis 2005). A similar observation was made by Atobatele and Ugwumba (2008).

Salinity: The mean salinity concentration in Merbok estuary is $19.92 \pm 6.62$ ppt, with the values ranging from 3.5 - 35 ppt. A downward trend was observed from $18.12 \mathrm{ppt}$ in October to $12.37 \mathrm{ppt}$ in January and $23.42 \mathrm{ppt}$ in February to $17.71 \mathrm{ppt}$ in May. Salinity in water varied $13.74-25.00 \mathrm{ppt}$, the highest was found in station 3 and the minimum in station 1 during wet season. Evaporation and freezing is responsible for increasing salinity whereas, rainfall, river run-off and melting of ice decreases salinity (Millero 2006). Salinity was positively correlated with conductivity. Due to addition of nutrient and carbonate from oxidation of plant and dissolution of calcium carbonate increases the concentration of carbonic ion and other trace elements which increases the conductivity in the ecosystem.

Transparency: Transparency in Merbok estuary has a mean value of $51.13 \pm$ $31.97 \mathrm{~cm}$, which ranged from $7.5-120 \mathrm{~cm}$. The maximum transparency $(68.27$ $\mathrm{cm})$ was found at Station 3 during wet season whereas, the minimum $(31.02 \mathrm{~cm})$ was recorded at Station 2 during dry season. Transparency may be influenced by suspended particulate matter by increased scattering of light transmission (Wetzel and Likens 2000). It may be due to land erosion, salinity, wave action result in increasing turbidity. 

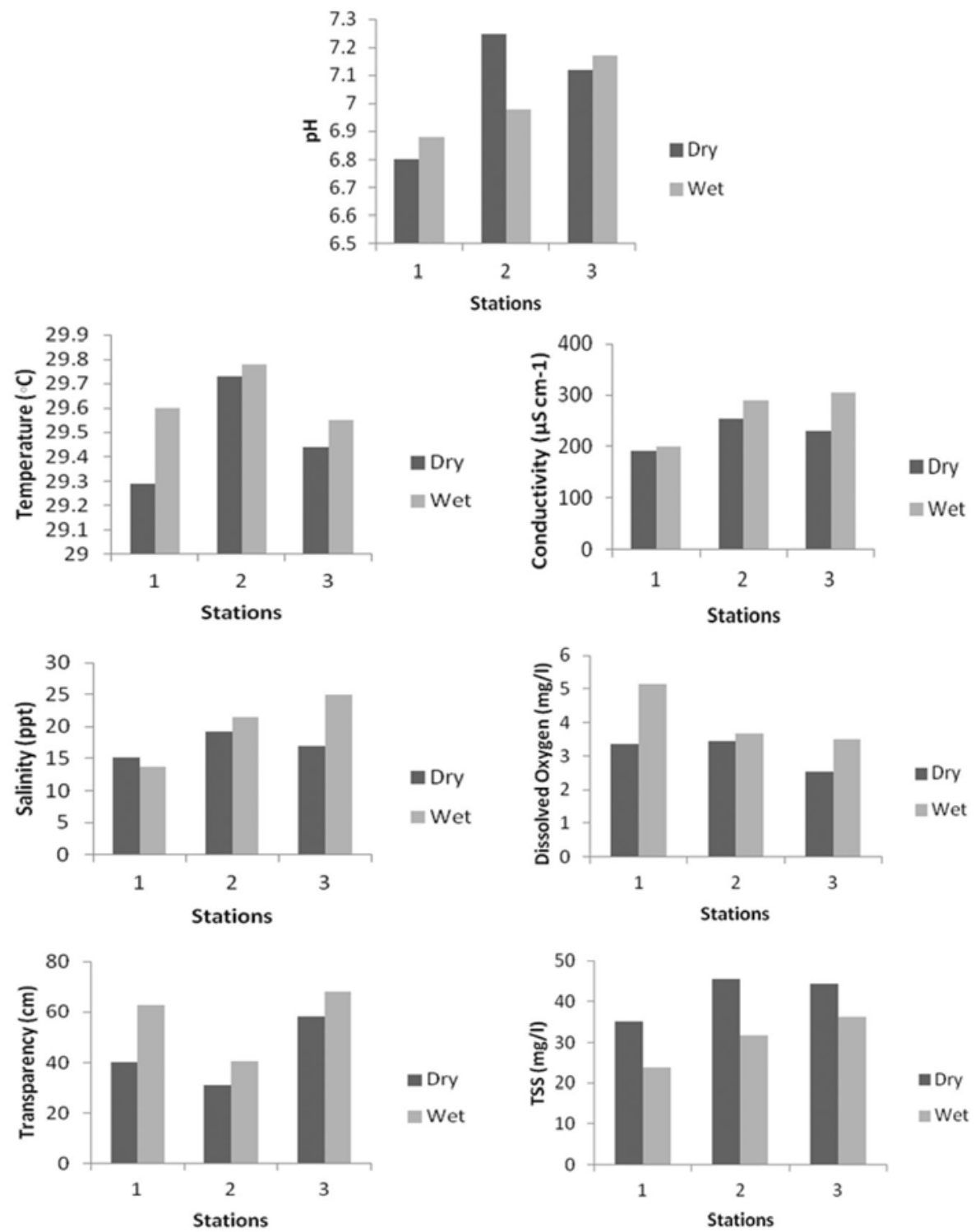

Fig. 2. Seasonal variation of physicochemical parameters at different stations of Merbok estuary

Total suspended solids (TSS): The mean for TSS is $41.50 \pm 25.09 \mathrm{mg} / 1$ with values ranging from $10-140 \mathrm{mg} / \mathrm{l}$. TSS varied from $23.89-45.55$ with the highest in Station 2 during dry season and the minimum in Station 1 during wet season. Due to erosion of catchment area and transport of nutrients from catchment enhance the nutrient concentration in sediment (Trott and Alongi 1999). Findings of this research comply with the previous research findings. 
Non parametric such as Kruskal Wallis $\mathrm{H}$ test found that water quality parameters were significantly different among the sampling months and stations ( $\mathrm{p}<0.05)$ (Ho 2006 and Coakes et al. 2006).

Water quality in Merbok estuary was different temporally and spatially. This study is essential for the sustainability of flora and fauna of the estuary and conservation of mangrove forest. Conservation is important to protect this area from pollution and destruction from natural calamities such as typhoon and tsunami and also anthropogenic factors such as nutrient loading and hazardous metal deposition. Continuous monitoring of water quality is pivotal to conerve the ecosystem of Merbok estuary.

Acknowledgements: The study was funded through USM grant number 1001/PBIOLOGI/844083 and Research University Grant 1001/PBIOLOGI /815048. The author acknowledges USM for providing all research facilities and TWAS for granting study fellowship to Kaniz Fatema.

\section{LITERATURE CITED}

APHA, 1991. Standard methods for the examination of water and waste water. 18th Ed. New York : American Public Health Association Inc

ADAM, S., PAWERT, M., LEHMANN, R., ROTH, B., MULlER, E., and TRIEBSKORN, R. 2001.Physicochemical and morphological characterization of two small polluted streams in Southwest Germany. J. of Aquatic Eco. Str. and Recov. 8: 179-194.

ATOBATELE, O. E., and UGWUMBA, O. A.2008. Seasonal variation in the physic chemistry of a small tropical reservoir (Aiba Reservoir, Iwo, Osun, Nigeria). African J. Biotech. 7(12): 1962-1971.

BELLOS, D. and SAWIDIS, T. 2005. Chemical pollution monitoring of the River Pinios (ThessaliaGreece). J. Environ Management 76: 282-292.

COAKES, J. S., STEED, L. and DZIDIC, P.2006. SPSS version 13.0 for Windows: analysis without anguish. John Wiley \& Sons Australia, Ltd, 166pp.

HORNE, A.J. and GOLDMAN, C. R.1994. Limnology, 2nd edition. New York: McGraw Hill Inc.

HO, R. 2006. Handbook of univariate and multivariate data analysis and interpretation with SPSS. Chapman \& Hall, London, $372 \mathrm{pp}$.

KJERFVE, B. 1979. Measurement and analysis of water current, temperature, salinity and density. In: Estuarine hydrography and sedimentation. Cambridge, 186-216.

FATEMA, K., WAN MAZNAH, W.O. and MANSOR, M.I. 2012. Fluctuation of water quality parameters in Merbok Estuary, Kedah, Malaysia, in Proc. 3rd International Conference on Environmental Research and Technology (ICERT), Penang, 476-479.

LEWIS, J. W.M.2000. Basis for the protection and management of tropical lakes. Lakes \& Reservoirs: Research and Management 5: 35-48.

MILLERO, F.J. 2006. Chemical Oceanography: $3^{\text {rd }}$ edition. Taylor \& Francis Group. 211-333 pp. 
ONG, J. E., GONG, W.K.,WONG, C. H., DIN, Z.H. and KJERFVE, B. 1991. Characterization of a Malaysian mangrove estuary. Estuaries and Coasts, 14(1): 38-48.

TROTT, L.A. and ALONGI, D.M. 1999. Variability in surface water chemistry and phytoplankton biomass in two tropical, tidally dominated mangrove creeks. Marine and Freshwater Res, 39: 451-457.

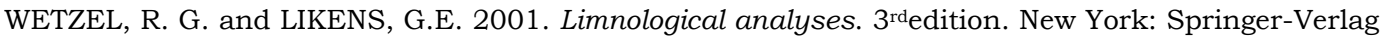
New York, Inc.

(Manuscript received on 9 January, 2013; revised on 5 May, 2013) 
Bangladesh J. Zool. 41(1): 21-27, 2013

\title{
COMPARATIVE EFFICACY OF FERTILIZERS APPLICATIONS ON THE PRODUCTION OF FRY OF MYSTUS GULIO (HAMILTON) IN NURSERY PONDS
}

\author{
Maliha Hossain Mou*, S. B. Saha and M. S. Khatun \\ Bangladesh Fisheries Research Institute, Brackishwater Station, \\ Paikgacha, Khulna
}

\begin{abstract}
Efficacy of different fertilizers on the growth and survival of brackishwater catfish, Mystus gulio (Hamilton) fry in nursery ponds has been evaluated with three fertilizer treatments (T) viz., T1 - only organic (cattle dung@ 5 tons/ha), T2 - only inorganic (urea@50 kg/ha + TSP@60 kg/ha) and T3 mixture of organic + inorganic (cattle dung@2.5 tons/ha + urea@25 kg/ha +TSP ( $30 \mathrm{~kg} / \mathrm{ha})$. After four weeks rearing, survival of fry was highest $(69.35 \pm 8.79 \%)$ in T1 which was significantly higher than those of T2 $(46.01 \pm 4.17 \%)$ and T3 $(57.19 \pm 6.22)$. But no significant difference in final length $(2.70-2.79 \mathrm{~cm})$ and final weight $(0.83-0.93 \mathrm{~g})$ among three treatments was observed. Physicochemical variables of water and planktons of different treatments were recorded and discussed.
\end{abstract}

Key words: Mystus gulio, survival, growth, supplementary feed, fertilizers.

\section{INTRODUCTION}

Mystus gulio (Hamilton), locally known as 'Nona tengra', is a euryhaline estuarine catfish commonly occurring in the coastal waters of Bangladesh and eastern coast of India. This species is supporting the coastal fisheries of Bangladesh to a great extent, both commercial and local point of view. But, availability of this fish in natural waterbodies is decreasing. For conservation and increasing supply of this fish, Bangladesh Fisheries Research Institute (BFRI) has developed breeding technology of this fish in 2006 (Alam et al. 2006, 2007). This has paved the way of establishing and expansion of aquaculture of the species. But, culture practice of this species has not yet been developed. Expansion of aquaculture of any fish is greatly dependent on its ensured supply of seed for grow-out pond. Nursing of yolk-absorbed hatchlings in the nursery pond seems to be very sensitive, as they pass through a critical period of switching over from planktonic feed to other feed and also need to adjust with new environment from indoor hatchery to outdoor earthen pond. Short term nursing of delicate spawn in nursery ponds is a prerequisite to ensure the reliable and regular supply of quality fry for stocking in grow out ponds at

*Corresponding author: Present address: Bangladesh Fisheries Research Institute, Freshwater Substation, Saidpur, Nilphamari. 
farmers' level. Available information regarding culture either at nursery phase or grow-out phase of $M$. gulio is very scanty. Different biological aspects including fecundity and food and feeding of this fish have been studied by David (1963) and Sarker et al. (2002). Pandian (1966) studied the feeding behaviour and reproductive cycle of $M$. gulio. Mukherjee et al. (2002) studied the spawning behaviour of M. gulio. Growth of larvae of this species fed with live and prepared feed has been studied by Islam et al. (2007). A trial on the growth and survival of M. gulio at different stocking densities as well as the effect of different dietary protein levels on its growth and maturity have been given by Begum et al. (2008a,b). The embryonic and larval development of this species was also reported by Begum et al. (2009). Culture potentials of freshwater catfish (M. cavasius) in monoculture management technique under different stocking densities have been reported by Kohinoor et al. (2004).

As fertilization enhances production of plankton which is the natural food of delicate hatchlings, management of nursery ponds of any fish needs proper fertilization. Organic manure like cattle dung is reported to enhance the production of zooplankton, while inorganic fertilizers enhance the production of phytoplankton (Alikunhi 1952, Alikunhi et al. 1955 and Bhimachar 1971). Thus, to obtain the optimum survival and growth rate of any fish fries in nursery ponds, it is of utmost importance to apply proper fertilizers in appropriate doses. No detailed information is available in Bangladesh on the relative effect of various organic and inorganic fertilizers on the growth and survival of brackishwater catfish fries in nursery ponds. In view of the above, the present study was undertaken to evaluate the effect of fertilizer on the growth and survival of brackishwater catfish, $M$. gulio fries in nursery ponds.

\section{MATERIAL AND METHODS}

Effect of different fertilizers on the growth and production of brackishwater catfish, Mystus gulio was carried out in nine nursery ponds of $60 \mathrm{~m}^{2}$ each following the experimental design as given Table 1 .

Table 1. Design of the experiment

\begin{tabular}{ll}
\hline Treatments $(\mathrm{T})$ & Name of fertilizers and dose \\
\hline T1 & Only organic (cattle dung @ 5 tons/ha) \\
T2 & Only inorganic (urea @ $50 \mathrm{~kg} / \mathrm{ha}$ and TSP @ $60 \mathrm{~kg} / \mathrm{ha}$ ) \\
T3 & Mixture of organic + inorganic (cattle dung @ 2.5 tons/ha, urea @ $25 \mathrm{~kg} / \mathrm{ha}$ \\
& and TSP@30 kg/ha)
\end{tabular}

Replications: three of each treatment

The ponds were prepared by sun drying followed by liming soil with $\mathrm{CaO} @$ $250 \mathrm{~kg} / \mathrm{ha}$ and then filling with tidal brackishwater up to $100 \mathrm{~cm}$ depth. Water 
of the ponds was treated with rotenone @1.5 ppm to kill unwanted fishes and then with dolomite @ 20ppm to increase the buffer capacity of the ponds. After 5 days, particular pond was fertilized with respective fertilizers and dose as given in the experimental design (Table 1). Five days after fertilization, dipterex @ 1 ppm was spread over the water surface followed by netting for mixing uniformly to kill aquatic crustaceans and insects. Twenty four hours after spreading of dipterex, four days old hatchlings (average length, $5 \mathrm{~mm}$ ) of $M$. gulio were stocked uniformly@250 Nos $/ \mathrm{m}^{2}$ in all ponds. From the second day of stocking, fish hatchlings were fed twice daily with a mixture of finely powdered mustard oil cake, rice bran and fish meal at the ratio of 2:3:5. The mixed feed contained approximately 30\% protein. Feed was supplied @ $6 \mathrm{~kg} /$ million of hatchlings which was raised to $10 \mathrm{~kg} /$ million hatchlings from the $6^{\text {th }}$ day of stocking. Subsequently, feed was increased by $5 \mathrm{~kg} /$ million of hatchlings every five days. In addition, from the first day of hatchlings stocking, the ponds were fertilized regularly at weekly interval with one fourth of the initial dose of fertilizer.

Growth and well being of the fries were checked at weekly interval. Physicochemical parameters of water viz., temperature, salinity, transparency, $\mathrm{pH}$, dissolved oxygen (DO) and alkalinity were determined following standard methods and plankton samples were analyzed at four days interval. Temperature of water was determined by an alcohol thermometer, salinity by refractometer (Atago, Japan), transparency by Secchi disk, $\mathrm{pH}$ by $\mathrm{pH}$ meter (Hanna, Italy) and DO and alkalinity by titrimetric method as mentioned in APHA (1992). The counting of phyto- and zooplankton was done by the "Direct census method" as described by Jhingran et al. (1969) using a Sedgewick-Rafter plankton counting cell. After four weeks of nursing, fish fries were harvested first by repeated netting, followed by draining the ponds with consequent growth and survival of fingerlings were estimated.

\section{RESULTS AND DISCUSSION}

Temperature and salinity of water within the study periods were $32.5-35.5^{\circ} \mathrm{C}$ and 3-5 ppt in all ponds. As shown in Fig. 1a, transparency of water was initially higher in all ponds and gradually decreased with the progress of culture periods. This variation in transparency was inversely related to plankton production. Minimum transparency of 27-59 cm was recorded in ponds fertilized with cattle dung only (T1) but it was $27-66 \mathrm{~cm}$ and $32-72 \mathrm{~cm}$ in ponds fertilized with only inorganic fertilizers (T2) and mixture of organic and inorganic fertilizers (T3). The $\mathrm{pH}$ of different ponds' water varied from 7.90 to 8.80 (Fig. 1b) which indicates that water of the ponds was weekly alkaline and congenial for nursing fries throughout the culture periods. Total alkalinity of all ponds at the beginning was 
almost same (179-180 mg/l) and later with the progress of culture periods these changed among different treatments as $180-250 \mathrm{mg} / 1,179-245 \mathrm{mg} / 1$ and $180-$ $240 \mathrm{mg} / 1$ in T1, T2 and T3, respectively (Fig. 1c). Dissolved oxygen (DO) was also always congenial for survival and growth of all kinds of fish fries in all the research ponds such as, 5.2-8.9 mg/1, 4.8-8.3 mg/1 and 5.1-8.5 mg/1 in T1, T2 and T3, respectively (Fig. 1d).
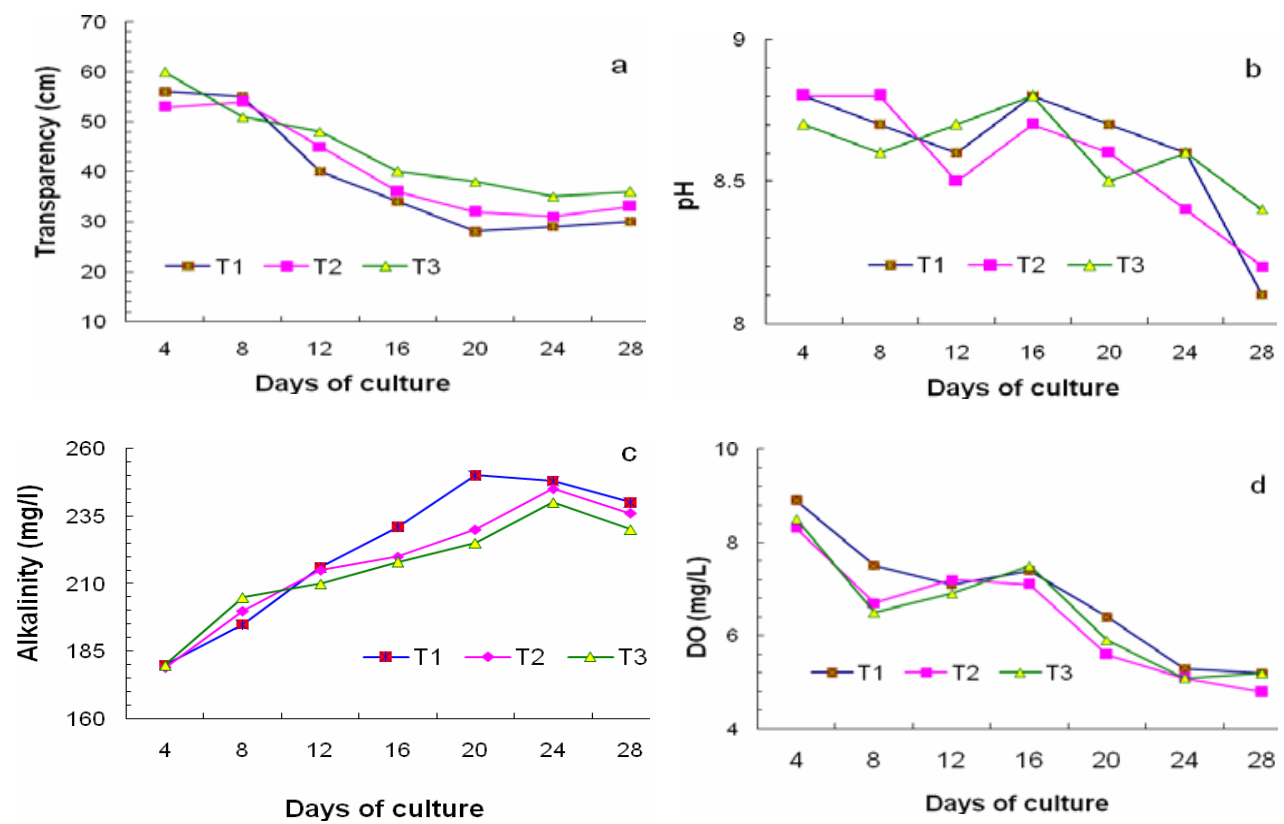

Fig. 1. Water quality parameters of the ponds used for nursing hatchlings of Mystus gulio $(\mathrm{T} 1=\mathrm{cattle}$ dung@ 5 t/ha, T2 =urea@50kg/ha+TSP@60 kg/ha, T3=cattle dung@2.5 t/ha + urea@25 kg/ha+TSP@30kg/ha)

Concentration of both phyto- and zooplankton was highest in ponds fertilized with only organic manure and that increased with the progress of culture periods. The quantitative production of phytoplankton were $15.00 \times 10^{3}-37.68 \times$ $10^{3}, 14.00 \times 10^{3}-31.70 \times 10^{3}$ and $12.80 \times 10^{3}-30.50 \times 10^{3}$ indiv./1 (Fig. 2a); while zooplankton were $4 \times 10^{2}-20 \times 10^{2}, 2 \times 10^{2}-18 \times 10^{2}$ and $3 \times 10^{2}-18 \times 10^{2}$ indiv./1 (Fig. 2b) in T1, T2 and T3, respectively. This production of phytoplankton was significantly higher in ponds treated with only organic manure than those of ponds treated with only inorganic fertilizers as well as mixture of organic and inorganic fertilizers. Almost similar production pattern was also obtained for zooplankton population in different stated treatments. However, in both types of plankton population, production (indiv./1) increased with the progress of culture periods, but, it was always lower in case of zooplankton population. Therefore, it 
is reasonable to assume that the supplementary feed gradually became essential and supplied to the ponds, the fries eventually adopted more and more to this kind of food. Besides, the left over supplementary feed was found to increase the organic and inorganic contents of the pond and subsequently, stimulated the growth of lower food chain as also opined by Goodwin and Hanson (1974).

In the stated conditions, the growth rates of fries were recorded as 2.70-2.73 $\mathrm{cm}, 2.75-2.82 \mathrm{~cm}$ and $2.64-2.74 \mathrm{~cm}$ in $\mathrm{T} 1, \mathrm{~T} 2$ and $\mathrm{T} 3$ ponds, respectively after four weeks of rearing (Table 2). Among the growth rates, the highest was obtained in ponds fertilized with only inorganic fertilizers, but such a growth in length in three other treatments was not significant. Again, in terms of weight (g), the highest growth of fry, $0.93 \mathrm{~g}$ was recorded from the ponds fertilized with inorganic fertilizers only while, $0.91 \mathrm{~g}$ and $0.83 \mathrm{~g}$ produced in ponds treated with only organic fertilizer as well as mixture of inorganic and organic fertilizer respectively, which means, there was also no significant change in growth in weight $(\mathrm{g})$ among the different treatments. However, mean survival of the stocked fries was highest $69.35 \pm 8.79 \%$ in ponds fertilized only with organic fertilizer (T1), which followed by $57.19 \pm 6.22 \%$ in ponds fertilized with mixture of organic and inorganic fertilizers (T3) as well as $46.01 \pm 4.17 \%$ in ponds fertilized with only inorganic fertilizers (T2). Thus, the differences in survival rates among three treatments were significant $(\mathrm{p}<0.01)$.
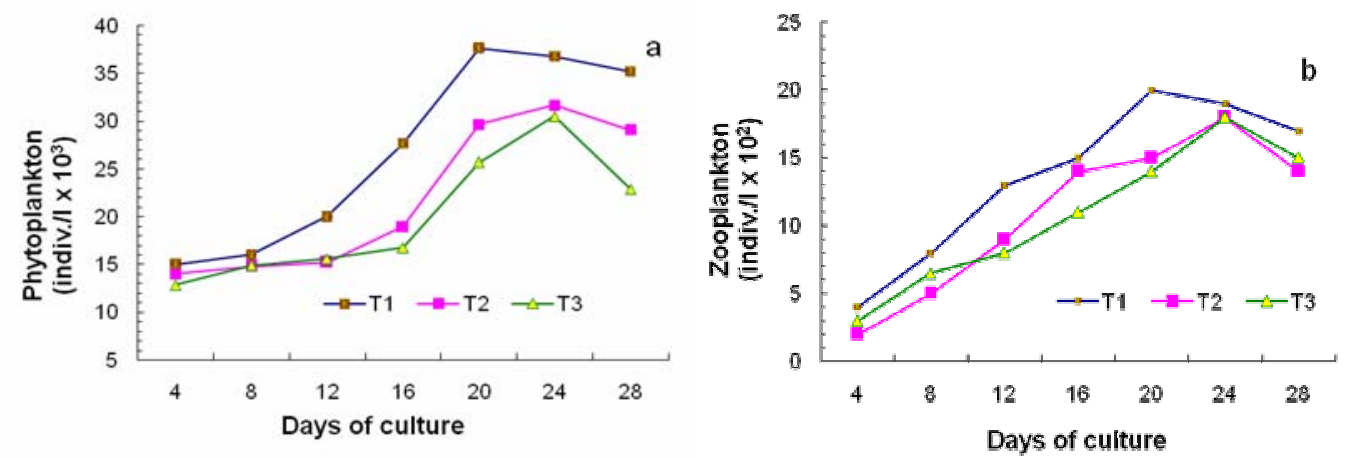

Fig. 2. Concentration of phyto- and zooplankton of the ponds used for nursing hatchlings of Mystus gulio $(\mathrm{T} 1=$ cattle dung@ 5 t/ha, T2=urea@50 kg/ha+TSP@60 kg/ha, T3= cattle dung@2.5 t/ha+urea@25 kg/ha+TSP@30kg/ha)

It has been observed that the extent of profit in commercial fry production processes largely dependent on the survival rate. Therefore, foods and other factors influence the growth and overall production of fry from per unit water area (Swingle 1968). Present study indicates that however, the growth of fishes was almost same in all the three treatments ponds, but survival rate was 
significantly high in ponds fertilized with only cattle dung. Physico-chemical conditions of all the ponds water were always convenient for the rearing of fry of the M. gulio, moreover, their growth to a large extent depends on the quality and quantity of feed available there in. In the present study, supplementary feed was

Table 2. Growth and survival of Mystus gulio in nursery ponds under different treatments. (Mean \pm SD)

\begin{tabular}{lcccc}
\hline Treatments & Replications & $\begin{array}{c}\text { Final length } \\
\text { (cm) }\end{array}$ & Final wt (g) & Survival (\%) \\
\hline T1 & R1 & 2.70 & 0.90 & 60.56 \\
(Cattle dung @ 5 tons/ha) & R2 & 2.73 & 0.92 & 78.13 \\
& R3 & 2.73 & 0.91 & 69.36 \\
& Mean & $2.72 \pm 0.017^{\mathrm{a}}$ & $0.91 \pm 0.01^{\mathrm{a}}$ & $69.35 \pm 8.79 \mathrm{a}$ \\
T2 & $\mathrm{R} 1$ & 2.82 & 0.90 & 47.19 \\
(Urea @ 50 kg/ha 8TSP @ & R2 & 2.75 & 0.95 & 41.73 \\
60 kg/ha) & R3 & 2.80 & 0.93 & 49.46 \\
& Mean & $2.79 \pm 0.036^{\mathrm{a}}$ & $0.93 \pm 0.025^{\mathrm{a}}$ & $46.01 \pm 4.17 \mathrm{~b}$ \\
T3 & $\mathrm{R} 1$ & 2.74 & 0.86 & 54.79 \\
(Cattle dung @ 2.5 & R2 & 2.64 & 0.80 & 64.25 \\
tons/ha, urea @ 25 kg/ha & R3 & 2.72 & 0.84 & 52.52 \\
and TSP @ 30 kg/ha) & Mean & $2.70 \pm 0.053^{\mathrm{a}}$ & $0.83 \pm 0.031^{\mathrm{a}}$ & $57.19 \pm 6.22 \mathrm{c}$ \\
\hline
\end{tabular}

*Figures with different superscript differ significantly.

supplied based on the quantity of fries stocked. But, availability of natural feed was different in different ponds, being more in ponds with organic manure as revealed by the plankton production (Fig. 2). Therefore, it may suggest that the observed higher survival rate of fries in ponds while fertilized with only organic manure could be due to high availability of natural food. Such a presumption needs further research to come into conclusion.

\section{LITERATURE CITED}

ALAM, M.J., BEGUM, M., ISLAM, M.A. and PAL, H.K. 2006. Spawning behaviour and induced breeding of an estuarine catfish, Mystus gulio(Ham.) Bangladesh J. Fish. Res. 10(2): 101-109.

ALAM, M.J., BEGUM, M., ISLAM, M.A. and PAL, H.K. 2007. Artificial breeding and seed production of nonatengra (Mystus gulio). Extension Booklet No. 30. Bangladesh Fisheries Research Institute, Brackishwater Station, Paikgacha, Khulna. 9p.

ALIKUNHI, K.H. 1952. On the food of young carp fry. J. Zool. Soc. India 4(1): 77-84.

ALIKUNHI, K.H., CHOUDHURY, H. and RAMACHANDRAN, V. 1955. On the mortality of plankton in their nursery ponds and the role of plankton in their survival and growth. Indian J. Fish. 2(2): 257-312.

APHA. 1992. Standard Methods for the Examination of Water and Waste Water. 18th ed., American Public Health Association, Washington, D.C. 
BEGUM, M., ABDUlLAH-AL MAMUN, PAL, H.K. and ALAM, M.J. 2008a. Effects of stocking density on growth and survival of Mystus gulio in nursery ponds. Bangladesh J. Fish. Res. 12(2):179186.

BEGUM, M., PAL, H.K., ISLAM, M.A. and ALAM, M.J. 2008b. Formulation of quality fish feeds from indigenous raw materials and their effects on growth and maturity of Mystus gulio. J. Bangladesh Agril. Univ. 6(2): 355-360.

BEGUM, M., PAL, H.K., ISLAM, M.A. and ALAM, M.J. 2009. Embryonic and larval development of Mystus gulio (Ham.). Bangladesh J. Fish. Res. 13(2):169-177.

BHIMACHAR, B.S. 1971. Food of the carp hatchlings. Indian Fmg. March: 45-49.

DAVID, A. 1963. Sexual dimorphism, fecundity and food of the estuarine bagrid, Mystus gulio (Ham.). Proc. Nat. Acad. Sci. India 33(3): 385-410.

GOODWIN, N. and HANSON, J. 1974. The aquaculture of freshwater prawns, Macrobrachium rosenbergii species. Proceedings of the Workshop on the culture of freshwater prawns, St. Petersberg, Fla. 95 p.

ISLAM, M.A., BEGUM, M., ALAM M.J., PAL, H.K. and SHAH, M.M.R. 2007. Growth and survival of estuarine catfish (Mystus gulio Ham.) larvae fed on live and prepared feeds. Bangladesh J. Zool. 35(2): 325-330.

JHINGRAN, V.G., NATARAJAN, A.V., BANERJEA, S.M., and DAVID, A. 1969. Methodology of reservoir fisheries investigation in India. Bull. Cent. Inland Fish. Res. Inst. Barrackpore, India 12:109 p.

KALIYAMURTHY, M. 1981. Spawning biology of Mystus gulio in lake Pulikat. Indian J. Fish. 8(1\&2): 36-40.

KOHINOOR, A.H.M., MOMTAZ BEGUM and HUSSAIN, M.G. 2004. Culture potentials of gulsha (Mystus cavasius) in monoculture management under different stocking densities. Bangladesh $J$. Fish. Res. 8(2): 95-100.

MUKHERJEE, M., PRAHARAJ, A. and DAS, S. 2002. Conservation of endangered fish stocks through artificial propagation and larval rearing technique in West Bengal, India. Aquacult. Asia 7(2): 811.

PANDIAN, T.J. 1966. Feeding and reproductive cycle of the fish Mystus gulio in the Cooum backwaters, Madras. Indian J. Fish. 13(1\&2): 322-333.

SARKER, P.K., PAL, H.K., and RAHMAN, M.M. 2002. Observation on the fecundity and gonadosomatic index of Mystus gulio in brackishwater of Bangladesh. Online J. Biol. Sci. 2(4): 235-237.

SWINGLE, H.S. 1968. Biological means of increasing productivity. In: T.V.R. Pillay (ed.) FAO Fish Rep. 4: 243-257. 